\title{
Air-steam gasification of sewage sludge in a bubbling bed reactor: Effect of alumina as a primary catalyst
}

\author{
Juan Manuel de Andrés*, Adolfo Narros, María Encarnación Rodríguez \\ Department of Chemical E Environmental Engineering, Universidad Politécnica de Madrid, (UPM), c/ José Gutiérrez Abascal 2, 28006 Madrid, Spain
}

\section{A R T I C L E I N F O}

Keywords:

Sewage sludge gasification

Primary catalyst

Bubbling fluidised bed

Gasifying agents

\begin{abstract}
A B S T R A C T
Numerous references can be found in scientific literature regarding biomass gasification. However, there are few works related to sludge gasification. A study of sewage sludge gasification process in a bubbling fluidised bed gasifier on a laboratory scale is here reported. The aim was to find the optimum conditions for reducing the production of tars and gain more information on the influx of different operating variables in the products resulting from the gasification of this waste. The variables studied were the equivalence ratio (ER), the steambiomass ratio (SB) and temperature. Specifically, the ER was varied from 0.2 to 0.4 , the SB from 0 to 1 and the temperature from $750{ }^{\circ} \mathrm{C}(1023 \mathrm{~K})$ to $850^{\circ} \mathrm{C}(1123 \mathrm{~K})$. Although it was observed that tar production could be considerably reduced (up to $72 \%$ ) by optimising the gasification conditions, the effect of using alumina (aluminium oxide, of proven efficacy in destroying the tar produced in biomass gasification) as primary catalyst in air and air-steam mixture tests was also verified. The results show that by adding small quantities of alumina to the bed ( $10 \%$ by weight of fed sludge) considerable reductions in tar production can be obtained (up to 42\%) improving, at the same time, the lower heating value (LHV) of the gas and carbon conversion.
\end{abstract}

\section{Introduction}

Sewage sludge is the liquid or semi-liquid waste generated in wastewater treatment plants. The amount of sludge produced in Spain and Europe has increased in last years. This increase is expected to continue [1] as a result of population growth and more stringent quality standards for waste waters [2].

The most widely used management alternatives for sewage sludge are agricultural use, incineration and landfilling, but in recent years, pyrolysis, gasification and wet oxidation have generated growing interest $[3,4]$. European legislation lays down restrictions for tipping organic material in landfills [5]. There is a strong social opposition to waste incineration and there are several constrains in the EU to alternative waste management systems such as direct use for cultivation [6].

Sewage sludge gasification is a technology that leads to a reduction in the volume of waste, the elimination of pathogens and fixes the heavy metals, thereby meeting the requirements imposed by the social and legislative framework [7]. During the process, gases are produced that can be used to generate energy or used as raw material in chemical synthesis processes. The substoichiometric conditions of the process reduce the formation of nitrogen oxides and sulphur oxides, heavy metal emissions, flying ash, dioxins and furans [4]. However, one of the main problems to be solved is tar production.

\footnotetext{
* Corresponding author. Tel.: +34 913363203; fax: +34913363009. E-mail address: jdeandres@etsii.upm.es (J.M. de Andrés).
}

Tars are complex mixtures of condensable hydrocarbons, aromatic compounds, oxygen-containing hydrocarbons and polycyclic aromatic hydrocarbons (PAH) [8]. These compounds can condense in pipes and filters and obstruct them, can affect the fuel line and the injectors of internal combustion engines and condense in the compressors or transfer lines, making the use of gases impossible for many applications $[9,10]$.

Tar elimination can be achieved by different methods, such as optimising the conditions of gasification [8], using physical systems (scrubbers, filters, cyclones, etc. [11]), thermal cracking [12,13] or catalytic cracking [14]. Tar removal technologies can be classified into primary (when carried out inside the gasifier) or secondary (when carried out outside the gasifier) [8].

A large amount of research has studied the effect of the various primary methods on the composition of the products of biomass gasification on a fluidised bed, specifically focusing on tar production [9,15-18]. These works have demonstrated the performance of calcined dolomite and olivine as catalysts for eliminating tar in gasification with air [15], steam [16] and steam- $\mathrm{O}_{2}$ mixtures [9]. Although olivine is more resistant to wear than calcined dolomite in fluidised bed processes, calcined dolomite appears to be more active in the destruction of tars $[17,18]$.

The effect of secondary methods of tar reduction in biomass gasification has also been studied [19-,21]. A comparison has been made of the capacity of nickel and calcined dolomite, calcite and magnesite catalysts for cleaning raw hot gas from biomass steam gasification [19]. With a three-stage system comprising a fluidised bed biomass gasifier with air, a fixed bed reactor of calcined dolomite, and 
a commercial nickel catalyst reactor, tar concentrations of 1-2 mg/ $\mathrm{Nm}^{3}$ have been obtained [20]. Tar reductions of up to $88 \%$ have also been obtained in gases from a biomass fluidised bed gasifier with air using four different types of calcined dolomite. In these experiments it was seen how the reductions increased on increasing $\mathrm{Fe}_{2} \mathrm{O}_{3}$ content in the catalyst [21]. Although the catalytic action increases with the calcination of the catalyst, the materials become more friable [22].

This paper deals with the effect of some gasification parameters, such as temperature, ER and SB, on sewage sludge gasification products. The results analysis has focused on the composition, production and LHV of the gases, on tar production, cold gas efficiency and carbon conversion. The results were compared with those existing in the bibliography for biomass gasification in order to know if the different characteristics of these materials have any influence on the products obtained, since the properties of the fuel play an important part during the conversion process [23].

Besides this work, the effect of in-bed use of alumina was also tested. The catalytic activity of this material (similar to that of dolomite) is related to its complex mixture of aluminium, oxygen and hydroxyl ions that produces both acid and base sites [24]. His porous structure increases the residence time of the tars in the bed by promoting the cracking and steam reforming reactions of the tars $[25,26]$. As the main innovation of this work, a set of tests with alumina were carried out using not only air but also air-steam mixtures as gasifying agents.

\section{Materials and methods}

\subsection{Materials}

The dried sludge samples came from urban wastewater treatment plants and consisted of spherical aggregate of approximately $2-5 \mathrm{~mm}$ diameter. The water content, ash content and other characteristics of the sludge are shown in Table 1. The lower heating value (LHV) of the sludge was $11.5 \mathrm{MJ} / \mathrm{kg}$ and was calculated from the modified Dulong's formula. The sludge was crushed and sieved to obtain a particle of between 300 and $500 \mu \mathrm{m}$, the same as for the alumina on tests with catalyst. The alumina (Spheralite 505) was supplied by Axens Procatalyse Catalysts \& Adsorbents with specifications as described in Manyà et al. [26]. Silica sand was used as bed material.

\subsection{Laboratory scale plant}

Fig. 1 shows a diagram of the installation where the experiments were conducted. The reactor used was a stainless steel (AISI $316 \mathrm{~L}$ ) fluidised bed reactor with a total height of $700 \mathrm{~mm}$ and an inner diameter of $32 \mathrm{~mm}$. There is a freeboard at the top of the reactor with

Table 1

Characterisation of sludge from wastewater treatment plant (analysis in triplicate).

\begin{tabular}{llll}
\hline Parameter $^{\mathrm{a}}$ & & Sludge $^{\mathrm{b}}$ & Analytical method \\
\hline Moisture (\%) & & $6.4-7.5$ & UNE-EN 12880-2001 \\
Organic mat. (\%) & & $53.3-58.7$ & UNE-EN 12879-2001 \\
Ash (\%) & & $46.7-41.3$ & UNE-EN 12879-2001 \\
pH & & 6.9 & UNE-EN 12176-1998 \\
Total carbon (\%) & & $3.7-4.5$ & LECO CHNS-932 \\
Nitrogen (\%) & & 4.8 & \\
Hydrogen (\%) & & 0.9 & \\
Sulphur (\%) & $\mathrm{Cd}$ & $\mathbf{1 - 4 . 4}$ & UNE-EN 13346-2001 \\
Heavy metals (mg/kg) & $\mathrm{Cu}$ & $387-418$ & \\
& $\mathrm{Ni}$ & $52-64$ & \\
& $\mathrm{~Pb}$ & $93-226$ & \\
& $\mathrm{Zn}$ & $\mathbf{1 1 7 2 - 1 2 8 3}$ & \\
& $\mathrm{Hg}$ & $\mathbf{1 . 3 - 4 . 2}$ & \\
& $\mathrm{Cr}$ & $\mathbf{1 2 8 - 1 9 9}$ & \\
& & & \\
& &
\end{tabular}

\footnotetext{
a Dry basis values, except moisture and $\mathrm{pH}$.
}

b Value interval for three analytical assays. an inner diameter of $46 \mathrm{~mm}$. The bed height is kept at $100 \mathrm{~mm}$ by a concentric pipe $(12.7 \mathrm{~mm}$ outer diameter) which goes through the distributor plate $(0.1 \mathrm{~mm}$ pore size) and lets the overflowing material be collected and stored in a discharge tank. Some stainless steel balls were placed under the distributor plate to pre-heat the gasifying agent before it reached the bed. The sludge was fed by a dosing system comprising a hopper, a controlled screw feeder and a launch screw. The launch screw was inserted into the reactor a few millimetres above the distributor plate by a $12.7 \mathrm{~mm}$ outer diameter pipe. This pipe was water-cooled to prevent pyrolysis of the sludge before entering the reactor [27]. The assembly (bed and freeboard) were heated by an electric furnace. The air entering the reactor was regulated using a mass flow controller. By means of two rotameters, part of the gasification air was diverted to the screw feeder to help the sludge enter the reactor while the rest was introduced through the distributor plate. In the air-steam mixture tests, a peristaltic pump was used to introduce water into the reactor.

In order to remove the particles entrained by the gases produced, the equipment was fitted with a cyclone and a micronic filter. Both devices were placed inside a hot box $\left(250{ }^{\circ} \mathrm{C} ; 523 \mathrm{~K}\right)$ to prevent condensation of the tars. The gas leaving the hot box was cooled in 5 condensers containing isopropanol placed over an ice bath (following a similar system to that for tar protocol, CEN/TS 15439:2006 [28]), most of the tars and water being collected. Placed behind the condensers was a water filter, a silica gel filter and a cotton filter to complete the cleaning of the gases. Gas production was measured by a mass flow meter. The gas composition was determined by means of a micro gas chromatograph (Micro-GC, Varian CP-4900) connected at the end of the process line to know the percentage volume of $\mathrm{N}_{2}, \mathrm{O}_{2}$, $\mathrm{H}_{2}, \mathrm{CO}, \mathrm{CO}_{2}, \mathrm{CH}_{4}, \mathrm{C}_{2} \mathrm{H}_{6}$ and $\mathrm{C}_{2} \mathrm{H}_{4}$. The time interval between analyses was $5 \mathrm{~min}$. To measure tar production the isopropanol-tar solutions were distilled to eliminate the absorbent (isopropanol). After distillation, the residue (tars) was dried at room temperature until constant weight. Finally, the sample was weighed. The char content was determined according the method used by Rapagná et al. [16].

\subsection{Experimental conditions}

The tests have been planned to find out the influence of the following parameters: temperature, equivalence ratio, steam and presence of alumina.

- Temperature. Tests were performed at temperatures of $750^{\circ} \mathrm{C}$ $(1023 \mathrm{~K}), 775^{\circ} \mathrm{C}(1048 \mathrm{~K}), 800^{\circ} \mathrm{C}(1073 \mathrm{~K}), 825^{\circ} \mathrm{C}(1098 \mathrm{~K})$ and $850^{\circ} \mathrm{C}(1123 \mathrm{~K})$.

- Equivalence ratio (ER). The ER, defined as the ratio between the flow rate of the air introduced into the reactor and the stoichiometric flow rate of the air required for a complete combustion of the sludge, was modified for each temperature. The values were $0.2,0.3$ and 0.4 .

- Steam. A set of tests were carried out setting the ER at 0.3 , modifying the temperature $\left(750^{\circ} \mathrm{C}(1023 \mathrm{~K}), 800^{\circ} \mathrm{C}(1073 \mathrm{~K})\right.$ and $850^{\circ} \mathrm{C}$ $(1123 \mathrm{~K})$ ) and introducing steam until a steam-to-biomass ratio (S/ $B$ ), defined as the flow rate of steam fed to the reactor divided by the flow rate of sludge (dry and ash free), of $0,0.5$ and 1 was reached. It was decided to set the ER at 0.3 because after the first set of tests it was observed that under these conditions, tar production was relatively low $(11 \mathrm{mg} / \mathrm{g} d a f)$ and the LHV of the gases remained at acceptable levels $\left(4 \mathrm{MJ} / \mathrm{Nm}^{3}\right)$.

- Alumina. Different quantities of catalyst (alumina) were placed in the gasifier $(0 \%, 10 \%$ and $15 \%$ by weight of fed sludge), the temperature was modified $\left(750{ }^{\circ} \mathrm{C}(1023 \mathrm{~K}), 800{ }^{\circ} \mathrm{C}(1073 \mathrm{~K})\right.$ and $850^{\circ} \mathrm{C}(1123 \mathrm{~K})$ ) and the ER was set at 0.3 .

- Alumina and steam. Tests were performed adding alumina ( $10 \%$ by weight of fed sludge) at a temperature of $800^{\circ} \mathrm{C}(1073 \mathrm{~K})$, ER 0.3 and modifying the $\mathrm{S} / \mathrm{B}$ ratio $(0,0.5$ and 1$)$. The tests were carried out at $800{ }^{\circ} \mathrm{C}(1073 \mathrm{~K})$ because problems were found to stabilise the 


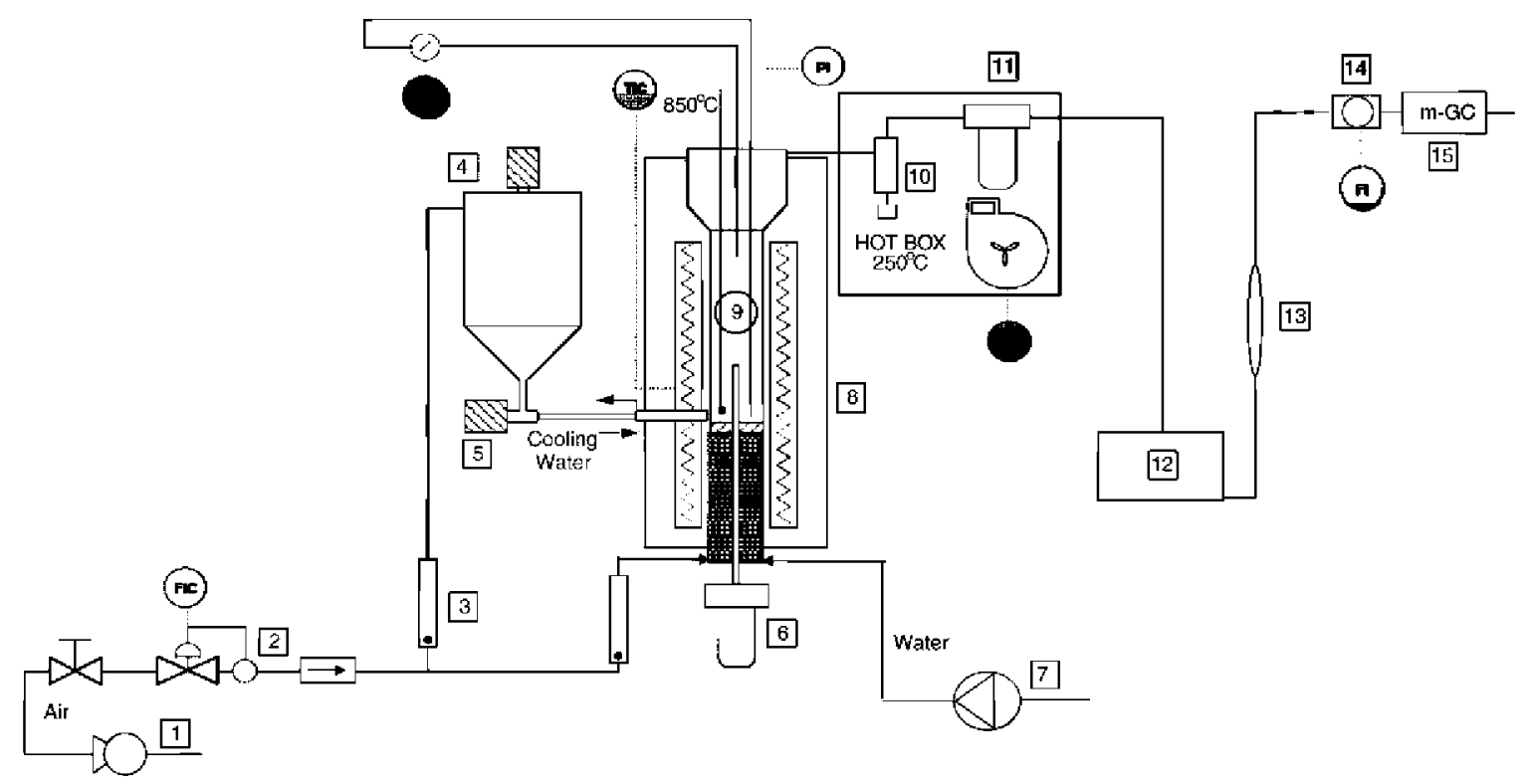

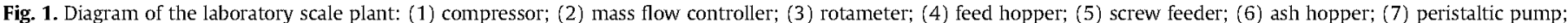
(8) furnace; (9) reactor; (10) cyclone; (11) hot filter; (12) condensation train; (13) water filters, silica gel and cotton; (14) mass flow meter; (15) micro gas-chromatograph.

temperature at $850^{\circ} \mathrm{C}(1123 \mathrm{~K})$ with steam in the tests with no catalyst.

The conditions and results of the tests carried out are shown in Tables 2 and 3. Prior to each test $80 \mathrm{~g}$ of silica sand (or sand/catalyst mixture in the proportion as reported in Table 3 ) were placed in the gasifier in the right proportions. Once the temperature of the test had been reached, the gasifier was continuously fed with sludge and a specific sand-catalyst mixture, as reported in Tables 2 and 3. In order to avoid the effect of the transient period [29], tests were running along $30 \mathrm{~min}$ in order to reach stable conditions, and after that, the tests were continued for $50 \mathrm{~min}$.

\section{Results}

\subsection{Influence of temperature and equivalence ratio in air gasification}

Fig. 2 shows the evolution of the average gas composition as a function of temperature for different ER in the tests performed with air and without addition of alumina. Higher temperatures favour hydrogen production. The concentration of $\mathrm{CH}_{4}$ increases slightly with temperature because higher temperatures produce more intense volatilisations [30] and the cracking reactions (generation of $\mathrm{H}_{2}$ and light hydrocarbons) prevail over reforming reactions (generation of $\mathrm{H}_{2}$ and $\mathrm{CO}$ from light hydrocarbons).

Table 2

Results of gasification experiment without catalyst. Effect of temperature, equivalence ratio (ER) and steam-biomass ratio (SB).

\begin{tabular}{|c|c|c|c|c|c|c|c|c|c|c|c|c|c|c|c|c|}
\hline \multirow[t]{2}{*}{ Parameters } & \multirow[t]{2}{*}{ Units } & \multicolumn{15}{|c|}{ Test number } \\
\hline & & 1 & 2 & 3 & 4 & 5 & 6 & 7 & 8 & 9 & 10 & 11 & 12 & 13 & 14 & 15 \\
\hline \multirow[t]{2}{*}{ Temperature } & $\mathrm{K}$ & 1023 & 1073 & 1123 & 1023 & 1073 & 1123 & 1023 & 1073 & 1123 & 1023 & 1073 & 1123 & 1023 & 1073 & 1123 \\
\hline & ${ }^{\circ} \mathrm{C}$ & 750 & 800 & 850 & 750 & 800 & 850 & 750 & 800 & 850 & 750 & 800 & 850 & 750 & 800 & 850 \\
\hline $\mathrm{u} / \mathrm{u}_{\mathrm{mf}}$ & & 3.6 & 3.8 & 4 & 3.6 & 3.8 & 4 & 3.6 & 3.8 & 4 & 3.6 & 3.8 & 4 & 3.6 & 3.8 & 4 \\
\hline $\mathrm{ER}$ & & 0.2 & 0.2 & 0.2 & 0.3 & 0.3 & 0.3 & 0.4 & 0.4 & 0.4 & 0.3 & 0.3 & 0.3 & 0.3 & 0.3 & 0.3 \\
\hline$S / B$ & & & & & & & & & & & 0.5 & 0.5 & 0.5 & 1.0 & 1.0 & 1.0 \\
\hline Sludge & $\mathrm{g} / \mathrm{min}$ & 2.2 & 2.2 & 2.2 & 1.4 & 1.4 & 1.4 & 1.1 & 1.1 & 1.1 & 1.4 & 1.4 & 1.4 & 1.4 & 1.4 & 1.4 \\
\hline Sand & $\%$ fed sludge & 20 & 20 & 20 & 20 & 20 & 20 & 20 & 20 & 20 & 20 & 20 & 20 & 20 & 20 & 20 \\
\hline WHSV & $\mathrm{h}^{-1}$ & 2.4 & 2.4 & 2.4 & 1.6 & 1.6 & 1.6 & 1.2 & 1.2 & 1.2 & 1.6 & 1.6 & 1.6 & 1.6 & 1.6 & 1.6 \\
\hline Composition & Dry basis & & & & & & & & & & & & & & & \\
\hline $\mathrm{H}_{2}$ & $\%$ & 9.8 & 14.0 & 16.4 & 7.6 & 10.4 & 12.1 & 3.2 & 8.5 & 9.7 & 9.9 & 11.0 & 15.5 & 10.0 & 12.0 & 16.1 \\
\hline $\mathrm{N}_{2}$ & $\%$ & 60.9 & 52.2 & 47.7 & 65.1 & 60.8 & 57.7 & 74.9 & 65.3 & 63.3 & 60.8 & 59.2 & 53.8 & 60.4 & 58.5 & 53.1 \\
\hline $\mathrm{CH}_{4}$ & $\%$ & 3.7 & 4.9 & 5.7 & 2.7 & 3.0 & 3.3 & 1.0 & 2.4 & 2.1 & 2.8 & 3.1 & 3.2 & 2.9 & 2.7 & 3.0 \\
\hline $\mathrm{CO}$ & $\%$ & 7.2 & 10.7 & 12.6 & 6.9 & 8.0 & 10.1 & 4.3 & 6.9 & 8.2 & 7.7 & 8.4 & 10.4 & 7.8 & 8.6 & 10.1 \\
\hline $\mathrm{CO}_{2}$ & $\%$ & 14.2 & 13.6 & 13.0 & 14.1 & 14.1 & 13.1 & 14.1 & 13.8 & 13.9 & 14.8 & 14.8 & 14.1 & 15.6 & 15.2 & 14.7 \\
\hline $\mathrm{C}_{2} \mathrm{H}_{6}$ & $\%$ & 0.15 & 0.10 & 0.07 & 0.14 & 0.09 & 0.04 & 0.09 & 0.07 & 0.03 & 0.07 & 0.04 & 0.03 & 0.06 & 0.03 & 0.02 \\
\hline $\mathrm{C}_{2} \mathrm{H}_{4}$ & $\%$ & 2.6 & 3.2 & 3.3 & 2.1 & 2.2 & 2.4 & 0.8 & 1.5 & 1.4 & 1.9 & 2.0 & 1.5 & 1.8 & 1.6 & 1.5 \\
\hline LHV gas & $\mathrm{MJ} / \mathrm{Nm}^{3}$ & 3.4 & 4.8 & 5.6 & 2.8 & 3.3 & 3.9 & 1.3 & 2.7 & 2.9 & 3.2 & 3.5 & 4.2 & 3.2 & 3.5 & 4.2 \\
\hline HHV gas & $\mathrm{MJ} / \mathrm{Nm}^{3}$ & 3,7 & 5,2 & 6,1 & 3,0 & 3,6 & 4,2 & 1,4 & 3,0 & 3,2 & 3,4 & 3,8 & 4,6 & 3,5 & 3,8 & 4,6 \\
\hline$Y_{\text {gas }}$ & $\mathrm{Nm}^{3} / \mathrm{kg}$ sludge, daf & 1.9 & 2.0 & 2.0 & 2.5 & 2.5 & 2.6 & 2.9 & 3.1 & 3.1 & 2.4 & 2.6 & 2.8 & 2.5 & 2.6 & 2.8 \\
\hline$C_{\text {tar }}$ & $\mathrm{g} / \mathrm{Nm}^{3}$ & 17.3 & 14.1 & 10.2 & 11.8 & 7.6 & 4.3 & 6.6 & 4.8 & 3.0 & 11.2 & 7.2 & 4.0 & 10.9 & 6.9 & 3.9 \\
\hline$Y_{\text {tar }}$ & $\mathrm{mg} / \mathrm{g}$ sludge, daf & 32.3 & 28.1 & 20.7 & 29.0 & 19.2 & 11.2 & 19.5 & 14.7 & 9.1 & 27.3 & 18.6 & 10.9 & 26.9 & 18.2 & 10.8 \\
\hline GMB & $\%$ & 96.7 & 97.2 & 95.3 & 98.9 & 96.9 & 96.9 & 97.8 & 97.6 & 99.4 & 96.5 & 99.7 & 97.3 & 95.4 & 97.5 & 95.0 \\
\hline $\mathrm{Xc}$ & $\%$ & 54.0 & 67.3 & 72.8 & 66.2 & 71.3 & 77.9 & 61.6 & 79.5 & 89.1 & 72.2 & 79.7 & 86.7 & 74.7 & 79.8 & 87.6 \\
\hline $\mathrm{X}_{\mathrm{H} 2 \mathrm{O}}$ & $\%$ & & & & & & & & & & 4.1 & 4.1 & 22.2 & 10.0 & 13.3 & 23.3 \\
\hline $\mathrm{GE}_{\mathrm{LHV}}$ & $\%$ & 28.7 & 43.2 & 50.7 & 30.4 & 37.4 & 45.5 & 16.6 & 38.1 & 42.3 & 35.2 & 41.0 & 53.1 & 35.6 & 41.1 & 53.0 \\
\hline $\mathrm{GE}_{\mathrm{HHV}}$ & $\%$ & 28,9 & 43,4 & 51,6 & 30,8 & 38,0 & 46,1 & 16,9 & 38,9 & 43,3 & 35,8 & 41,9 & 54,6 & 36,4 & 42,3 & 54,6 \\
\hline Char & $\mathrm{g} / \mathrm{kg} \mathrm{daf}$ & 87.3 & 69.8 & 71.1 & 88.3 & 56.0 & 37.4 & 45.4 & 38.6 & 12.8 & 37.2 & 16.5 & 13.2 & 34.7 & 14.9 & 14.9 \\
\hline
\end{tabular}


Table 3

Results of gasification experiment with catalyst. Effect of temperature, amount of catalyst and steam-biomass ratio (SB).

\begin{tabular}{|c|c|c|c|c|c|c|c|c|c|}
\hline \multirow[t]{2}{*}{ Parameter } & \multirow[t]{2}{*}{ Units } & \multicolumn{8}{|c|}{ Test number } \\
\hline & & 16 & 17 & 18 & 19 & 20 & 21 & 22 & 23 \\
\hline \multirow[t]{2}{*}{ Temperature } & $\mathrm{K}$ & 1023 & 1073 & 1123 & 1023 & 1073 & 1123 & 1073 & 1073 \\
\hline & ${ }^{\circ} \mathrm{C}$ & 750 & 800 & 850 & 750 & 800 & 850 & 800 & 800 \\
\hline $\mathrm{u} / \mathrm{u}_{\mathrm{mf}}$ & & 3.6 & 3.8 & 4 & 3.6 & 3.8 & 4 & 3.8 & 3.8 \\
\hline ER & & 0.3 & 0.3 & 0.3 & 0.3 & 0.3 & 0.3 & 0.3 & 0.3 \\
\hline S/B & & & & & & & & 0.5 & 1.0 \\
\hline Sludge & $\mathrm{g} / \mathrm{min}$ & 1.4 & 1.4 & 1.4 & 1.4 & 1.4 & 1.4 & 1.4 & 1.4 \\
\hline Alumina & $\%$ fed sludge & 10 & 10 & 10 & 15 & 15 & 15 & 10 & 10 \\
\hline Sand & $\%$ fed sludge & 10 & 10 & 10 & 5 & 5 & 5 & 10 & 10 \\
\hline WHSV & $h^{-1}$ & 1.6 & 1.6 & 1.6 & 1.6 & 1.6 & 1.6 & 1.6 & 1.6 \\
\hline Composition & Dry basis & & & & & & & & \\
\hline $\mathrm{H}_{2}$ & $\%$ & 8.0 & 12.3 & 15.0 & 8.8 & 12.1 & 14.2 & 13.3 & 15.2 \\
\hline $\mathrm{N}_{2}$ & $\%$ & 64.9 & 60.1 & 55.1 & 64.4 & 59.8 & 56.5 & 58.2 & 56.1 \\
\hline $\mathrm{CH}_{4}$ & $\%$ & 2.3 & 2.8 & 2.8 & 2.3 & 2.8 & 2.5 & 2.4 & 2.6 \\
\hline $\mathrm{CO}$ & $\%$ & 7.6 & 8.5 & 12.2 & 7.7 & 8.3 & 12.2 & 8.4 & 8.1 \\
\hline $\mathrm{CO}_{2}$ & $\%$ & 14.2 & 13.5 & 12.5 & 14.1 & 12.6 & 12.2 & 14.9 & 15.3 \\
\hline $\mathrm{C}_{2} \mathrm{H}_{6}$ & $\%$ & 0.06 & 0.05 & 0.02 & 0.05 & 0.05 & 0.02 & 0.03 & 0.03 \\
\hline $\mathrm{C}_{2} \mathrm{H}_{4}$ & $\%$ & 1.5 & 1.3 & 1.0 & 1.3 & 1.4 & 1.0 & 1.3 & 1.3 \\
\hline LHV gas & $\mathrm{MJ} / \mathrm{Nm}^{3}$ & 2.7 & 3.5 & 4.3 & 2.8 & 3.5 & 4.1 & 3.5 & 3.7 \\
\hline HHV gas & $\mathrm{MJ} / \mathrm{Nm}^{3}$ & 3,0 & 3,8 & 4,7 & 3,1 & 3,8 & 4,5 & 3,8 & 4,0 \\
\hline$Y_{\text {gas }}$ & $\mathrm{Nm}^{3} / \mathrm{kg}$ sludge, daf & 2.5 & 2.7 & 2.8 & 2.5 & 2.8 & 2.8 & 2.7 & 2.7 \\
\hline$C_{\text {tar }}$ & $\mathrm{g} / \mathrm{Nm}^{3}$ & 7.4 & 4.3 & 2.3 & 4.7 & 2.6 & 1.4 & 3.4 & 3.5 \\
\hline$Y_{\text {tar }}$ & $\mathrm{mg} / \mathrm{g}$ sludge, daf & 18.3 & 11.8 & 6.4 & 11.7 & 7.2 & 3.9 & 9.1 & 9.5 \\
\hline GMB & $\%$ & 99.0 & 100.3 & 100.9 & 100.1 & 102.8 & 101.0 & 99.9 & 96.4 \\
\hline$X_{C}$ & $\%$ & 68.4 & 73.1 & 85.5 & 69.4 & 71.4 & 83.3 & 79.0 & 80.8 \\
\hline $\mathrm{X}_{\mathrm{H} 2 \mathrm{O}}$ & $\%$ & & & & & & & 14.0 & 18.9 \\
\hline $\mathrm{GE}_{\mathrm{LHV}}$ & $\%$ & 30.6 & 41.1 & 53.5 & 32.3 & 41.3 & 51.1 & 42.4 & 45.6 \\
\hline $\mathrm{GE}_{\mathrm{HHV}}$ & $\%$ & 31,3 & 42,3 & 55,3 & 33,2 & 42,6 & 52,8 & 43,8 & 47,3 \\
\hline Char & $\mathrm{g} / \mathrm{kg}$ daf & 49.6 & 57.9 & 18.2 & 51.3 & 84.3 & 16.5 & 26.5 & 29.8 \\
\hline
\end{tabular}

CO production increases with temperature, which is due to incomplete combustion reactions and to the Boudouard and $\mathrm{CO}_{2}$ reforming reactions. This assertion is reinforced by the increase in the
$\mathrm{CO} / \mathrm{CO}_{2}$ ratio with temperature (Fig. 3). However, $\mathrm{CO}_{2}$ production slightly decreases with temperature. This behaviour does not follow such well-defined patterns as those of the $\mathrm{H}_{2}$ and $\mathrm{CO}$. This may be due
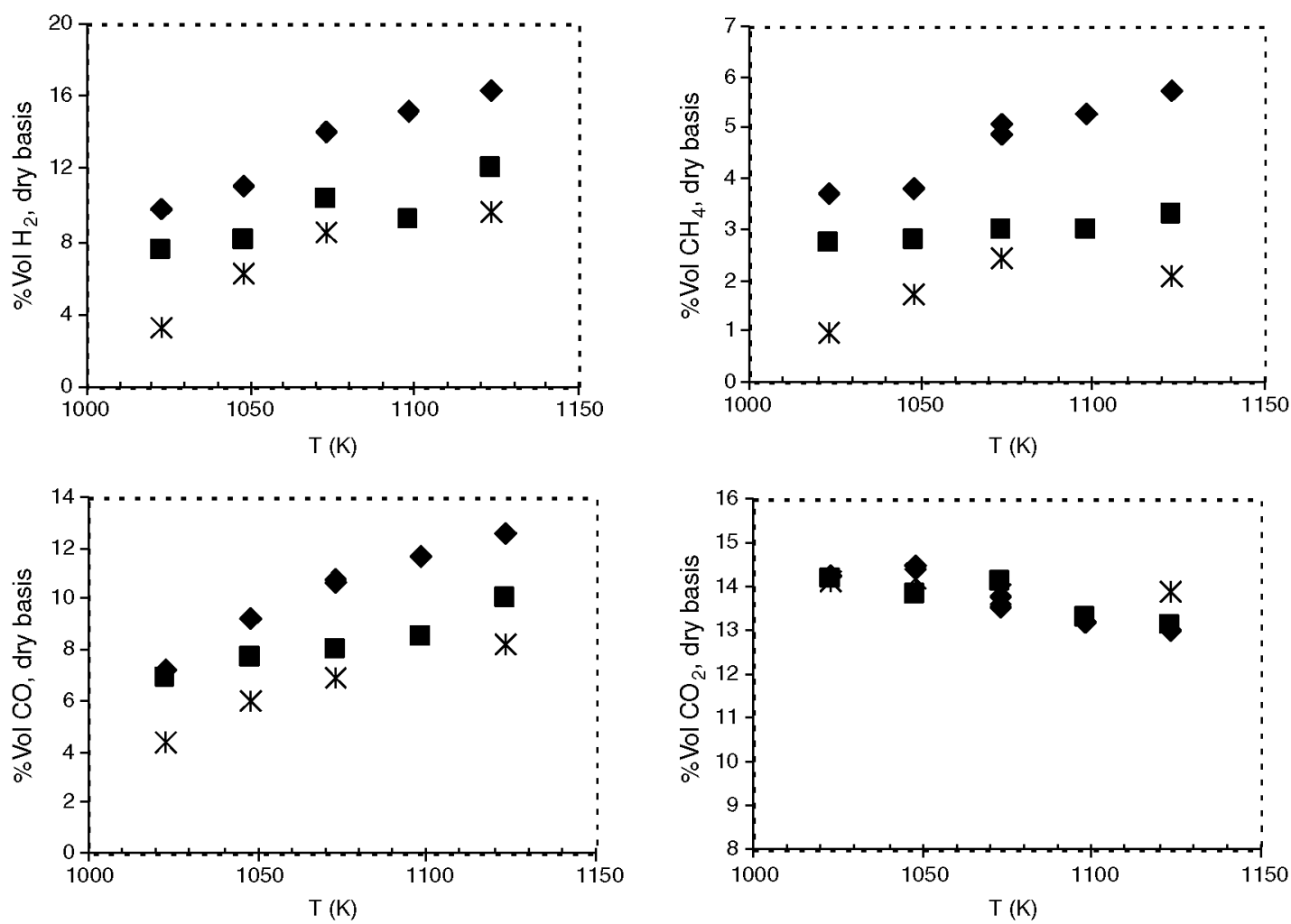

Fig. 2. Evolution of gas composition with temperature for different ER $(\diamond 0.2 ; 0.3 ; \nVdash 0.4)$. 


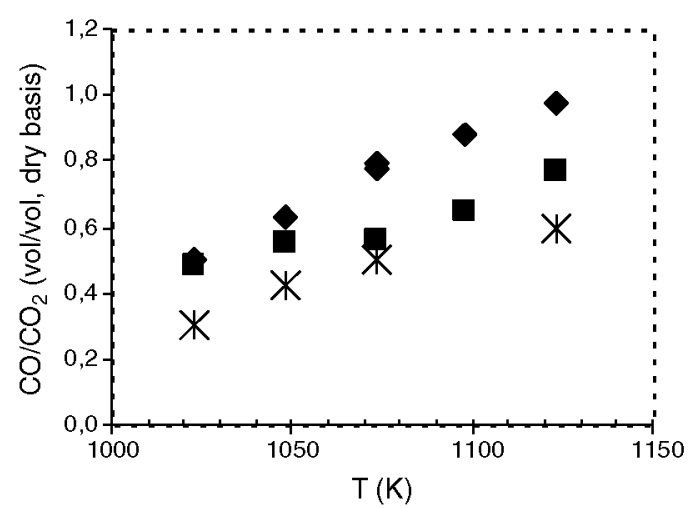

Fig. 3. Variation of $\mathrm{CO} / \mathrm{CO}_{2}$ ratio with temperature and $\mathrm{ER}(\boldsymbol{0 . 2} ; 0.3 ;$ ж 0.4$)$.

to the fact that $\mathrm{CO}_{2}$ production is not only a consequence of volatilisation of the organic fraction, but also due to the heterogeneous reactions of $\mathrm{CO}_{2}$ with char and tars [30].

The dependence of the composition of the gases on the ER for temperatures of $750{ }^{\circ} \mathrm{C}(1023 \mathrm{~K}), 800{ }^{\circ} \mathrm{C}(1073 \mathrm{~K})$ and $850^{\circ} \mathrm{C}(1123 \mathrm{~K})$ is shown in Fig. 4. $\mathrm{H}_{2}$ and $\mathrm{CO}$ production decreases as ER rises and temperature decreases. When the ER is high, oxidation reactions are favoured due to a higher oxygen content leading to greater amounts of $\mathrm{CO}_{2}$ and smaller amounts of $\mathrm{H}_{2}$ and $\mathrm{CO}$ [31]. At the same ER, $\mathrm{H}_{2}$ and $\mathrm{CO}$ production decreases at lower temperatures due to the lower importance of the reforming, cracking and water-gas reactions, all of which are endothermic. The production of $\mathrm{CH}_{4}$ and $\mathrm{C}_{\mathrm{n}} \mathrm{H}_{\mathrm{m}}$ decreases as ER rises (Table 2) due to partial oxidation reactions [15,32].

Fig. 5 shows the variations in tar concentrations under different gasification conditions. Tar content decreases in every case as temperature rises [8,33], which is a result of cracking of tars and

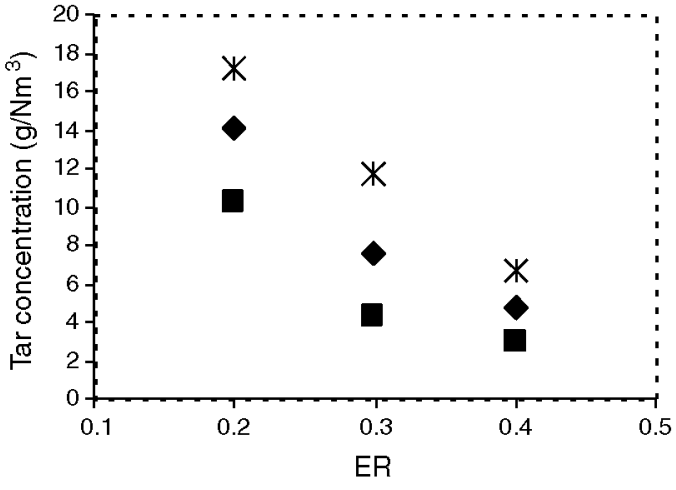

Fig. 5. Tar concentration for different temperatures ( $ж 1023 \mathrm{~K} ; \uparrow 1073 \mathrm{~K}$; $1123 \mathrm{~K})$ and equivalence ratios.

steam and $\mathrm{CO}_{2}$ reforming reactions [27]. At the same temperature, tar concentration decreases as ER increases due to the oxidation of tars.

Gas production and its lower heating value (LHV) were similar to that reported by other researchers [15,26] (Table 2, tests 1 to 9). Gas production increases with temperature and ER due to a more intense volatilisation of the sludge, the decomposition of the tars and conversion of the char [30]. Higher temperatures favour gasification reactions where combustible gases $\left(\mathrm{H}_{2}, \mathrm{CO}\right.$ and $\left.\mathrm{CH}_{4}\right)$ are produced. However, increases in the ER involve the oxidation part of these combustible gases resulting in a considerable loss of LHV.

The cold gas efficiency and carbon conversion in Fig. 6, calculated as in Olivares et al. [9] and Cao et al. [34] respectively, are comparable to those found by other authors for biomass and sludge [26,34,35]. The cold gas efficiency varies between $17 \%$ (at $750{ }^{\circ} \mathrm{C}(1023 \mathrm{~K}$ ) and ER 0.4 ) and $51 \%$ (at $850^{\circ} \mathrm{C}(1123 \mathrm{~K})$ and ER 0.2$)$ while carbon conversion varies between $54 \%$ (at $750^{\circ} \mathrm{C}\left(1023 \mathrm{~K}\right.$ ) and ER 0.2) and $89 \%$ (at $850^{\circ} \mathrm{C}(1123 \mathrm{~K}$ ) and ER 0.4 ).
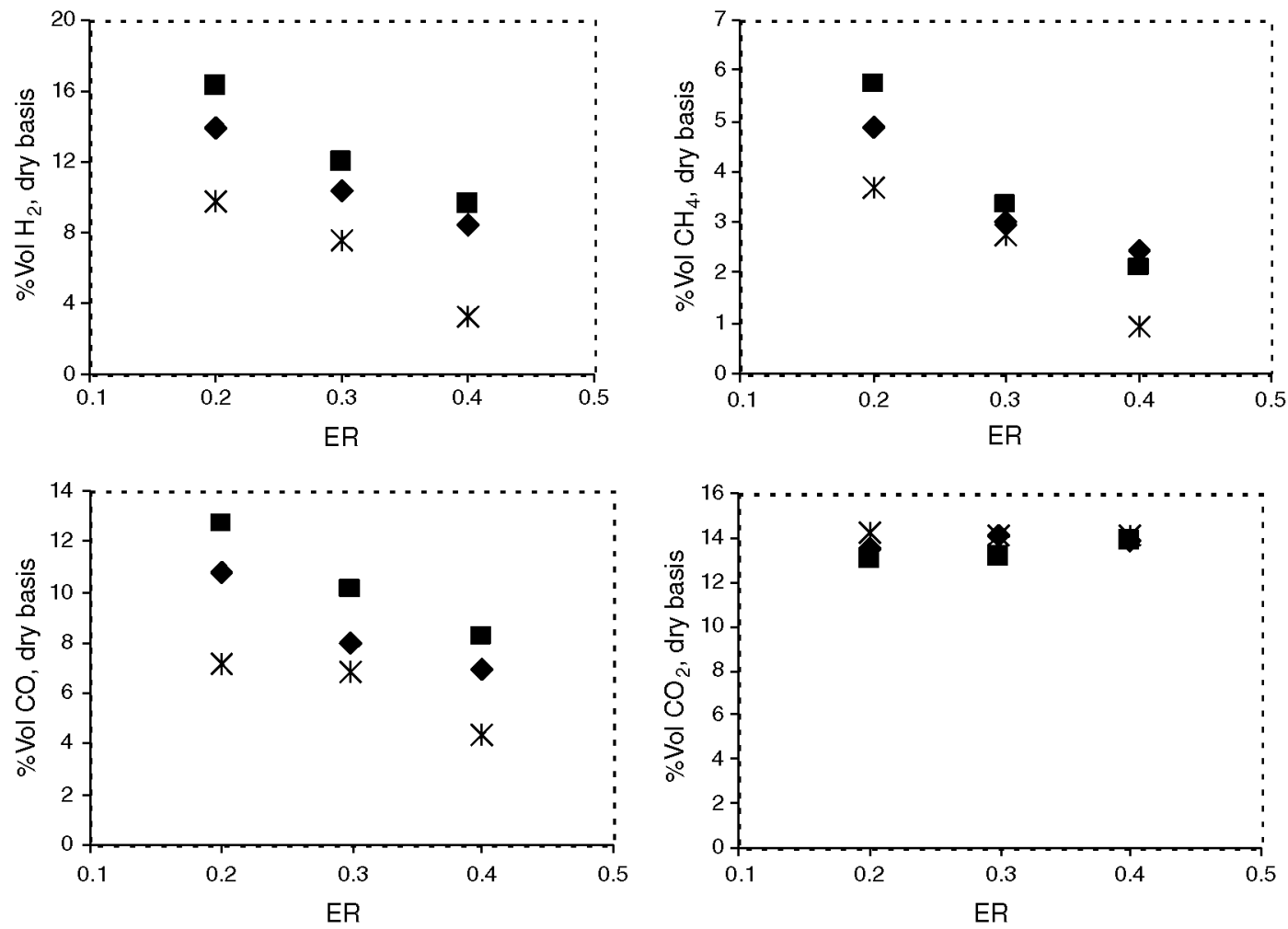

Fig. 4. Evolution of gas composition according to the variation of ER and temperature: $1023 \mathrm{~K} ; 1073 \mathrm{~K} ; \mathbf{\square} 1123 \mathrm{~K}$. 

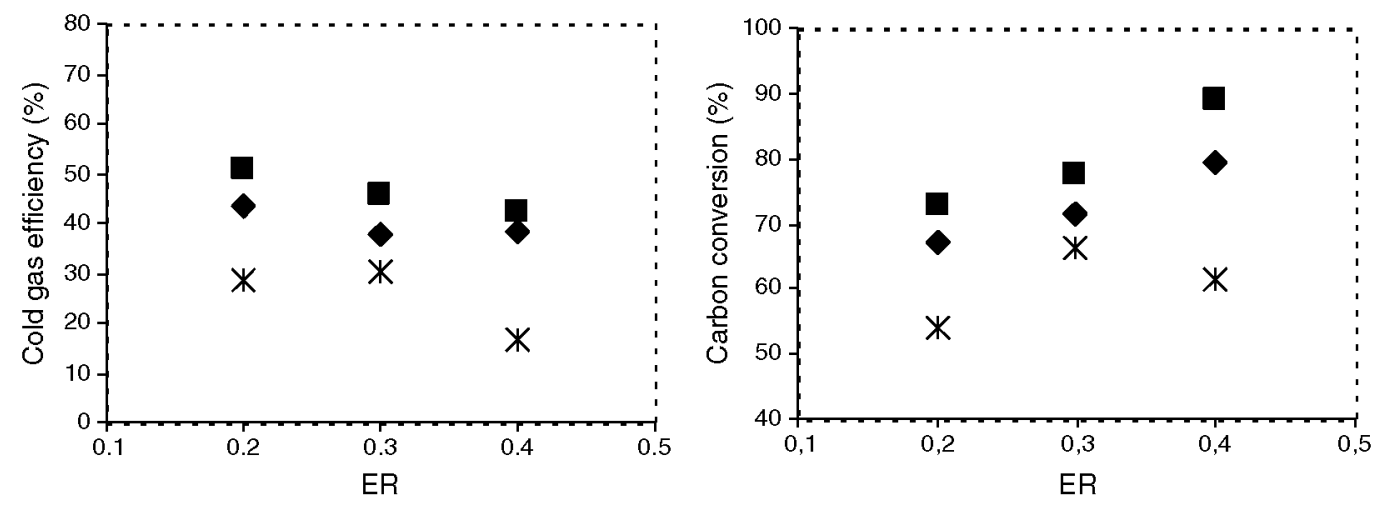

Fig. 6. Cold gas efficiency and carbon conversion for different ER and temperatures ( $1023 \mathrm{~K} ; 1073 \mathrm{~K} ; \mathbf{\square} 123 \mathrm{~K}$ ).

\subsection{Influence of steam as gasifying agent}

The results of the gasification tests conducted with steam are shown in Table 2, tests 10 to 15 . Fig. 7 shows the change in gas composition at different temperatures and ratios $\mathrm{SB}$, being $\mathrm{ER}=0.3$.

The results are similar to those found by Campoy et al. [36], the addition of steam increases hydrogen production due to the watergas-shift, steam reforming and water-gas (at the highest temperatures) reactions. This finding agrees with the great reduction in the production of light hydrocarbon $\mathrm{C}_{\mathrm{n}} \mathrm{H}_{\mathrm{m}}$ (Table 2) and with the increase in $\mathrm{CO}_{2}$ production. The $\mathrm{CO}$ production is slightly higher in the steam tests than in the air tests. These results differ from what has been observed by other authors [15,32,36,37], who found lower CO contents as SB increased due to the water-gas-shift reaction. This behaviour might be due to the prevalence of the reforming and gassolid reactions (Boudouard and water-gas), which are promoted by the gasification conditions and the gasifier design.

Tar production decreases in the presence of steam due to steam reforming reactions [15]. This fact, combined with the water-gas
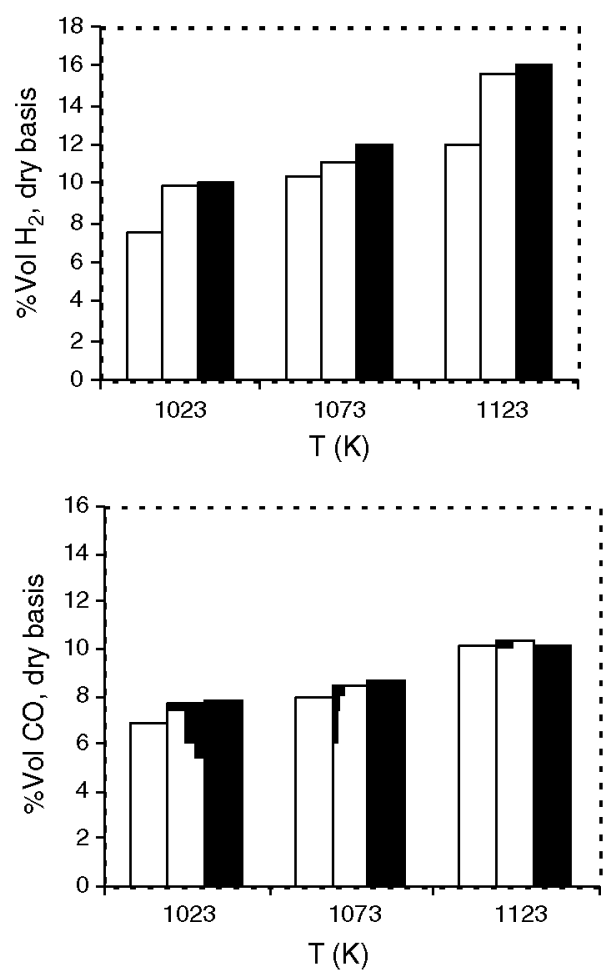

reaction between steam and char produces slight increases in $\mathrm{CO}$ and $\mathrm{H}_{2}$ production [10]. The smaller amount of char found in these tests (Table 2) strengthens this assertion. The variation in gas composition and more specifically the increase in $\mathrm{H}_{2}$ content, give rise to increases in the LHV of up to $15 \%$.

The addition of steam leads to a mean improvement of $14 \%$ in cold gas efficiency and $12 \%$ in carbon conversion. The maximum values for these parameters $\left(53 \%\right.$ and $88 \%$, respectively) are found at $850{ }^{\circ} \mathrm{C}$ $(1123 \mathrm{~K}$ ) and $\mathrm{SB}=1$.

\subsection{Effect of adding alumina to the bed}

Table 3 shows the results of the gasification tests with alumina as primary catalyst. In air gasification (tests 16 to 21 ), the alumina increases the production of $\mathrm{H}_{2}$ compared to the tests without catalyst for the whole range of temperatures, reaching contents of $15 \%$ by volume at $850^{\circ} \mathrm{C}(1123 \mathrm{~K})$. There is a tendency for $\mathrm{CO}$ production to rise, particularly at higher temperatures $\left(850^{\circ} \mathrm{C} ; 1123 \mathrm{~K}\right)$, and for $\mathrm{CH}_{4}$, $\mathrm{CO}_{2}$, and $\mathrm{C}_{\mathrm{n}} \mathrm{H}_{\mathrm{m}}$, production to decrease, which agrees with Manyà
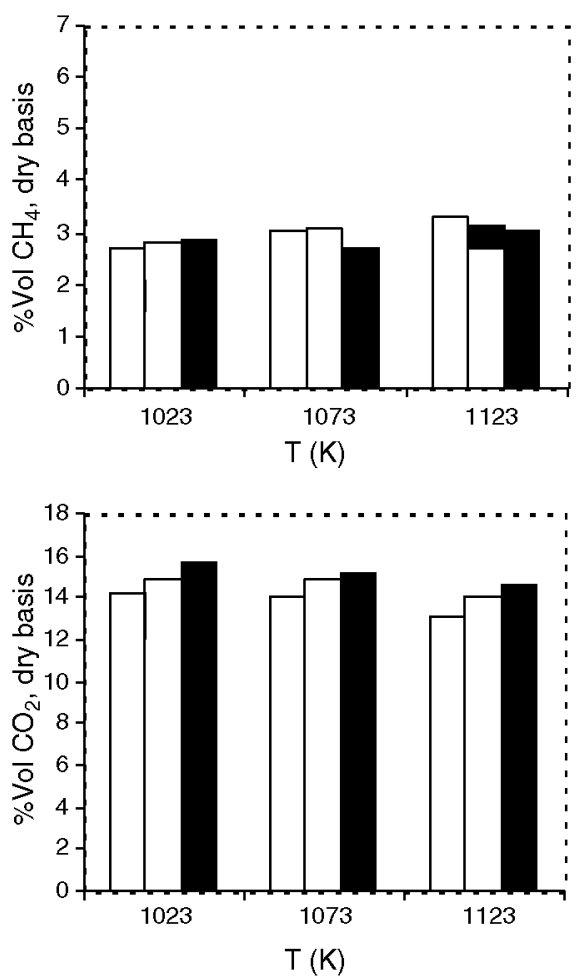

Fig. 7. Comparison of the composition of gasification gases at different temperatures, ER 0.3 and different SB values ( $\square 0$; 


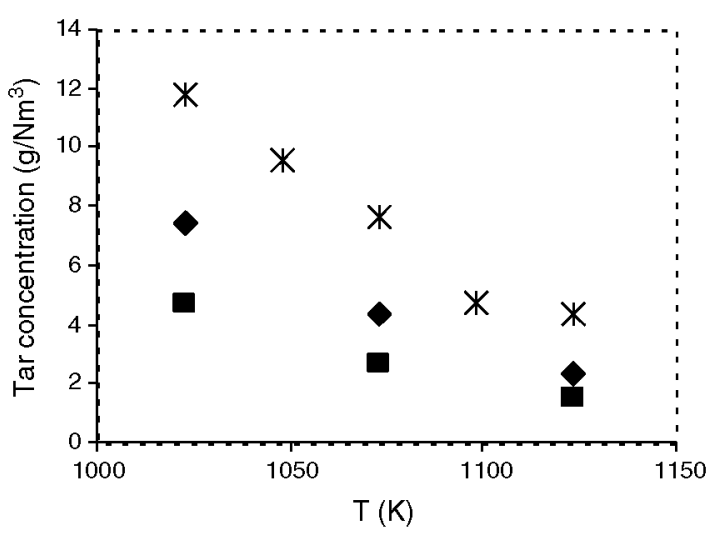

Fig. 8. Tar concentration for different temperatures and amounts of alumina in the feed ( $\%$ o no catalyst; $10 \%$ fed sludge; $15 \%$ fed sludge). ER $=0.3$.

et al. [26]. The results indicate that the presence of alumina favours cracking and $\mathrm{CO}_{2}$ reforming reactions, since, in these tests, where the water only comes from the sludge, the influence of water-gas-shift and steam reforming reactions is limited. Gas composition hardly varies when the amount of catalyst placed on the bed is modified.

Fig. 8 shows the decrease in tar content in gases using alumina. In the presence of alumina, tar reduction varies between $37 \%$, at $750{ }^{\circ} \mathrm{C}$ $(1023 \mathrm{~K})$ with $10 \%$ of catalyst in the feed and $65 \%$ at $850^{\circ} \mathrm{C}(1123 \mathrm{~K})$ with $15 \%$ of alumina in the feed. In previous works, tar production reduction close to $44 \%$ has been found using $8 \%$ by weight of alumina in the feed at $850^{\circ} \mathrm{C}(1123 \mathrm{~K})$ [26]. Similar results have been reported here $\left(43 \%\right.$ at $850{ }^{\circ} \mathrm{C}(1123 \mathrm{~K})$ with $10 \%$ alumina $)$. However, in contrast with Manyà et al. [26] where larger amounts of catalyst did not reduce tar production, this research has achieved additional reductions by increasing the catalyst added to the bed.

Cold gas efficiency and carbon conversion are higher in the presence of alumina due to a slight increase in gas production and in its LHV. On average, and compared to the tests without catalyst, cold gas efficiency is $10 \%$ higher and carbon conversion $5 \%$ higher.

Fig. 9 illustrates the gas composition and tar concentration found in tests with air but without alumina (test 5 ), tests with air and alumina (test 17) and tests with steam and alumina (tests 22 and 23). $\mathrm{H}_{2}$ production increases with steam-alumina up to $46 \%$ compared with the tests with air and without catalyst. Contrary to the tests without catalyst, $\mathrm{CO}$ production decreases with steam due to the water-gas-shift reaction. The predominance of this reaction not only explains the increase in the content of $\mathrm{H}_{2}$ and the decrease in $\mathrm{CO}$, but also the increase a)

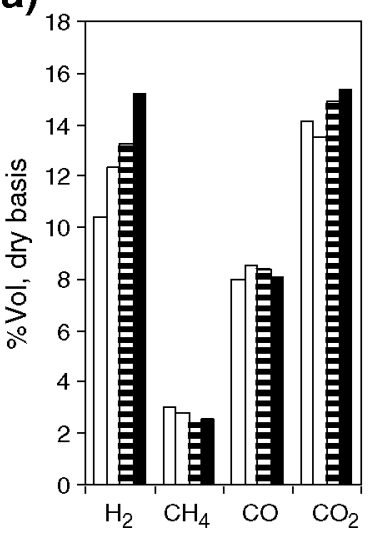

b)

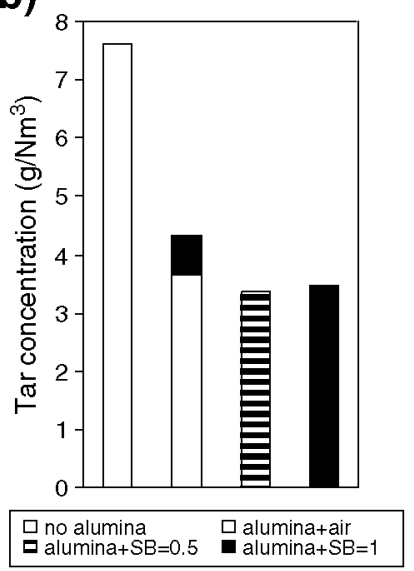

Fig. 9. Combined influence of steam and alumina ( $10 \%$ catalyst, $E R=0.3, T=1073 \mathrm{~K}$ ) in products of gasification: (a) gas composition; (b) tar concentration.
Table 4

Effect of alumina and steam on the production of gases, lower and higher heating value, cold gas efficiency and carbon conversion.

\begin{tabular}{llcccc}
\hline Parameter & Units & $\begin{array}{l}\text { Air without } \\
\text { alumina }\end{array}$ & $\begin{array}{l}\text { Air with } \\
\text { alumina }\end{array}$ & $\begin{array}{l}\text { Alumina and } \\
\text { steam }(\mathrm{SB}=0.5)\end{array}$ & $\begin{array}{l}\text { Alumina and } \\
\text { steam }(\mathrm{SB}=1)\end{array}$ \\
\hline LHV gas & $\mathrm{MJ} / \mathrm{Nm}^{3}$ & 3.3 & 3.5 & 3.5 & 3.7 \\
HHV gas & $\mathrm{MJ} / \mathrm{Nm}^{3}$ & 3.6 & 3.8 & 3.8 & 4.0 \\
$\mathrm{Y}_{\text {gas }}$ & $\mathrm{Nm}^{3} / \mathrm{kg}$ & 2.5 & 2.7 & 2.7 & 2.7 \\
& sludge, daf & & & & \\
$\mathrm{Xc}$ & $\%$ & 71.3 & 73.1 & 79.0 & 80.8 \\
$\mathrm{GE}_{\mathrm{LHV}}$ & $\%$ & 37.4 & 41.1 & 42.4 & 45.6 \\
$\mathrm{GE}_{\mathrm{HHV}}$ & $\%$ & 38.0 & 42.3 & 43.8 & 47.3 \\
\hline
\end{tabular}

in the concentration of $\mathrm{CO}_{2}$. The $\mathrm{CH}_{4}$ production decreases in the steam catalysed tests mainly due to the steam reforming reactions.

The reduction in tar content in the gasification tests with steamalumina is $20 \%$ compared with the tests with air-alumina and $55 \%$ compared with the tests with air and without catalyst (Fig. 9-b). As Table 4 shows, the presence of catalyst increases gas production compared with the tests without catalyst, but adding steam to the process does not seem to have a significant effect. Something similar occurs with the LHV, although the combined presence of catalyst and steam leads to increases in $\mathrm{H}_{2}$ at higher $\mathrm{SB}$, it also causes a reduction in $\mathrm{CO}$ and $\mathrm{CH}_{4}$ content due to water-gas-shift and steam reforming reactions, respectively. The final results are small variations in LHV when steam is added to the process. For these reasons, cold gas efficiency and carbon conversion tend to be slightly higher (between 8 and $9 \%$ ) at higher values of SB reaching a maximum increase of $11 \%$ at $\mathrm{SB}=1$.

\section{Conclusions}

In this work the combined influence of steam and alumina (as primary catalyst) on the products of gasification has been studied. Interest has focused on the composition, production and LHV of the gases, tar production, cold gas efficiency and carbon conversion.

In the absence of a catalyst, the introduction of steam into the gasification atmosphere increases hydrogen production and enhances the lower heating value of the gas, in addition tar production is reduced and the production of gases is slightly increased. The combination of alumina and air favours the production of $\mathrm{H}_{2}$ and $\mathrm{CO}$ especially at high temperatures $\left(850^{\circ} \mathrm{C} ; 1123 \mathrm{~K}\right)$, as well as a reduction in the production of $\mathrm{CH}_{4}, \mathrm{CO}_{2}$ and $\mathrm{C}_{\mathrm{n}} \mathrm{H}_{\mathrm{m}}$. It also significantly reduces tar content.

If steam is introduced in the presence of alumina, tar production is reduced even more. Generally speaking, steam has a more qualitative (it improves the composition of the gas from a higher hydrogen production point of view and a lower tar content) rather than quantitative influence as no significant changes are observed in gas production, in either LHV (the rise in $\mathrm{H}_{2}$ concentration is offset by a fall in $\mathrm{CO}$ and $\mathrm{CH}_{4}$ ), in cold gas efficiency or in carbon conversion.

As future lines of research we will consider conducting tests catalysed with steam at $850^{\circ} \mathrm{C}(1123 \mathrm{~K})$ and a study of the effects of the different primary catalysts on the gasification products, with the goal of producing a multi-purpose quality gas.

\section{Nomenclature}

daf dry and ash-free

ER equivalence ratio, defined as the air-to-fuel ratio divided by the air-to-fuel ratio for the stoichiometric combustion, \%

LHV lower heating value of the produced gas, $\mathrm{MJ} / \mathrm{Nm}^{3}$, dry basis HHV higher heating value of the produced gas, $\mathrm{MJ} / \mathrm{Nm}^{3}$, dry basis SB steam-to-biomass ratio, defined as the flow rate of steam fed to the reactor divided by the flow rate of sludge (daf).

$\mathrm{X}_{\mathrm{H} 2 \mathrm{O}} \quad$ water conversion in the gasifier (\%)

$\mathrm{u}$ superficial gas velocity in the gasifier bed, $\mathrm{cm} / \mathrm{s}$ 

$\mathrm{cm} / \mathrm{s}$

WHSV (weight hourly space velocity) (( $\mathrm{kg}$ sludge as received/h)/kg bed in the gasifier)

$\mathrm{Nm}^{3} \quad$ cubic meter, normal conditions $\left(0^{\circ} \mathrm{C}, 101 \mathrm{kPa}\right)$

$\mathrm{Y}_{\text {gas }} \quad$ gas yield, $\mathrm{Nm}^{3}$ dry gas $/ \mathrm{kg}$ sludge, daf

$\mathrm{C}_{\mathrm{tar}} \quad$ tar concentration, $\mathrm{g} / \mathrm{Nm}^{3}$

$\mathrm{Y}_{\mathrm{tar}} \quad$ tar yield, $\mathrm{mg} / \mathrm{g}$ sludge, daf

GMB global mass balance, \%

$\mathrm{X}_{\mathrm{c}} \quad$ carbon conversion, weight of carbon in the produced gas divided by weight of carbon in the sludge introduced in the gasifier

$\mathrm{GE}$ (cold gas efficiency) $=\mathrm{GE}_{\mathrm{LHV}}$ LHV of gas divided by the LHV of sludge; $\mathrm{GE}_{H H V}$ : $\mathrm{HHV}$ of gas divided by the $\mathrm{HHV}$ of sludge

\section{Acknowledgements}

This work has been partially funded by the Canal de Isabel II.

\section{References}

[1] J. Werther, T. Ogada, Sewage sludge combustion, Progress in Energy and Combustion Science 25 (1999) 55-116.

[2] Urban Waste Water Treatment Directive (UWWTD) (91/271/EEC), amended by Directive $98 / 15 / \mathrm{EC}$.

[3] A. Dominnguez, J.A. Menéndez, M. Inguanzo, J.J. Pis, Investigations into the characteristics of oils produced from microwave pyrolysis of sewage sludge, Fuel Processing Technology 86 (2005) 1007-1020.

[4] D. Fytili, A. Zabaniotou, Utilization of sewage sludge in EU application of old and new methods-a review, Renewable \& Sustainable Energy Reviews 12 (2008) 116-140.

[5] Council Directive 99/31/CE, 26 April 1999, on the landfill of waste.

[6] Sewage Sludge Directive $86 / 278 / \mathrm{EEC}$.

[7] A. Domínguez, J.A. Menéndez, J.J. Pis, Hydrogen rich fuel gas production from the pyrolysis of wet sewage sludge at high temperature, Journal of Analytical and Applied Pyrolysis 77 (2006) 127-132.

[8] L. Devi, Krzysztof J. Ptasinski, Frans J.J.G. Janssen, A review of the primary measures for tar elimination in biomass gasification processes, Biomass and Bioenergy 24 (2) (2003) 125-140.

[9] A. Olivares, M.P. Aznar, M.A. Caballero, J. Gil, E. Francés, J. Corella, Biomass Gasification: Produced Gas Upgrading by In-Bed Use of Dolomite, Industrial \& Engineering Chemistry Research 36 (1997) 5220-5226.

[10] J.F. González, S. Román, D. Bragado, M. Calderón, Investigation on the reactions influencing biomass air and air/steam gasification for hydrogen production, Fuel Processing Technology 89 (8) (2008) 764-772.

[11] J. Han, H. Kim, The reduction and control technology of tar during biomass gasification/pyrolysis: an overview, Renewable \& Sustainable Energy Reviews 12 (2008) 397-416.

[12] T.A. Milne, N. Abatzoglou, R.J. Evans, Biomass gasifier 'tars': their nature, formation and conversion, NREL/TP-570-25357, National Renewal Energy Laboratory, 1998.

[13] D. Dayton, A review of the literature on catalytic biomass tar destruction, Milestone Completion Report. National Renewable Energy Laboratory U.S., NREL/ TP-510-32815, 2002.

[14] D. Sutton, B. Kelleher, J.R.H. Ross, Review of literature on catalysts for biomass gasification, Fuel Processing Technology 73 (2001) 155-173.

[15] J. Gil, M.A. Caballero, J.A. Martín, M.P. Aznar, J. Corella, Biomass gasification with air in a fluidized bed: effect of the in-bed use of dolomite under different operation conditions, Industrial \& Engineering Chemistry Research 38 (1999) $4226-4235$

[16] S. Rapagná, N. Jand, A. Kiennemann, P.U. Foscolo, Steam-gasification of biomass in a fluidised-bed of olivine particles, Biomass and Bioenergy 19 (2000) 187-197.

[17] J. Corella, J.M. Toledo, R. Padilla, Olivine or dolomite as in bed additive in biomass gasification with air in a fluidized bed: Which is better? Energy and Fuels 18 (2004) 713-720.

[18] F. Miccio, B. Piriou, G. Ruoppolo, R. Chirone, Biomass gasification in a catalytic fluidized reactor with beds of different materials, Chemical Engineering Journal 154 (2009) 369-374

[19] J. Delgado, M.P. Aznar, J. Corella, Calcined dolomite magnesite and calcite for cleaning hot gas from a fluidized bed biomass gasifier with steam: life and usefulness, Industrial \& Engineering Chemistry Research 35 (1996) 3637-3643.

[20] I. Narváez, J. Corella, A. Orio, Fresh tar (from a biomass gasifier) elimination over a commercial steam reforming catalyst. Kinetics and effect of different variables of operation, Industrial \& Engineering Chemistry Research 36 (1997) 317-327.

[21] A. Orio, J. Corella, I. Narvàez, Performance of different dolomites on hot raw gas clearing from biomass gasification with air, Industrial \& Engineering Chemistry Research. 36 (1997) 3800-3808.

[22] G. Hu, S. Xu, S. Li, Ch. Xiao, S. Liu, Steam gasification of apricot stones with olivine and dolomite as downstream catalysts, Fuel Processing Technology 87 (2006) $375-382$.

[23] F. Miccio, O. Moersch, H. Spliethoff, K.R.G. Hein, Gasification of two biomass fuels in bubbling fluidized bed, Proceedings of 15th Conference on Fluidized Bed Combustion, ASME, 1999, pp. 108-120.

[24] Z. Abu El-Rub, E.A. Bramer, G. Brem, Review of catalysts for tar elimination in biomass gasification processes, Industrial \& Engineering Chemistry Research 43 (2004) 6911-6919.

[25] P.A. Simell, J.B. Brendenberg, Catalytic purification of tarry fuel gas, Fuel 69 (1990) 1219-1225.

[26] J.J. Manyà, J.L. Sánchez, A. Gonzalo, J. Arauzo, Air gasification of dried sewage sludge in a fluidized bed: effect of the operating conditions and in-bed use of alumina, Energy and Fuels 19 (2005) 629-636.

[27] I. Narvăez, A. Orío, M.P. Aznar, J. Corella, Biomass gasification with air in an atmospheric bubbling fluidized bed. Effect of six operational variables on the quality of the produced raw gas, Industrial \& Engineering Chemistry Research 35 (1996) 2110-2120

[28] CEN/TS 15439:2006: Biomass gasification, Tar and particles in product gases, Sampling and analysis. CEN Technical Specification.

[29] M. Aznar, A.E. González, J.J. Manyá, J.L. Sánchez, M.B. Murillo, Understanding the effect of the transition period during the air gasification of dried sewage sludge in a fluidized bed reactor, International Journal of Chemical Reactor Engineering 5 (2007), (art. A18)

[30] M. Campoy, A. Gómez-Barea, F.B. Vidal, P. Ollero, Air-steam gasification of biomass in a fluidised bed: process optimisation by enriched air, Fuel Processing Technology 90 (2009) 677-685.

[31] Pengmei Lv, Zhenhong Yuan, Longlong Ma, Chuangzhi Wu, Yong Chen, Jingxu Zhu, Hydrogen-rich gas production from biomass air and oxygen/steam gasification in a downdraft gasifier, Renewable Energy 32 (2007) 2173-2185.

[32] X.J. Guo, B. Xiao, S. Liu, Z. Hu, S.Y. Luo, M.Y. He, An experimental study on air gasification of biomass micron fuel (BMF) in a cyclone gasifier, International Journal of Hydrogen Energy 34 (2009) 1265-1269.

[33] X.T. Li, J.R. Grace, C.J. Lim, A.P. Watkinson, H.P. Chen, J.R. Kim, Biomass gasification in a circulating fluidized bed, Biomass and Bioenergy 26 (2004) 171-193.

[34] Y. Cao, Y. Wang, J.T. Riley, W.-P. Pan, A novel biomass air gasification process for producing tar-free higher heating value fuel gas, Fuel Processing Technology 87 (2006) 343-353.

[35] K.G. Mansaray, A.E. Ghaly, A.M. Al-Taweel, F. Hamdullahpur, V.I. Ugursal, Air gasification of rice husk in a dual distributor type fluidized bed gasifier, Biomass and Bioenergy 17 (1999) 315-332.

[36] M. Campoy, A. Gómez-Barea, A. Villanueva, P. Ollero, Air-steam gasification of biomass in a fluidized bed under simulated autothermal and adiabatic conditions, Industrial and Engineering Chemistry Research 47 (2008) 5957-5965.

[37] P.M. Lv, Z.H. Xiong, J. Chang, C.Z. Wu, Y. Chen, J.X. Zhu, An experimental study on biomass air-steam gasification in a fluidized bed, Bioresource Technology 95 (2004) 95-101. 